UDC 616.2-008.64-02:[616.98:578.834]-085:615.816.2

DOI: $10.15587 / 2519-4798.2020 .213104$

\title{
EFFECT OF DIFFERENT VARIANTS OF NON-INVASIVE VENTILATION ON THE COURSE AND OUTCOMES IN PATIENTS WITH HYPOXEMIC RESPIRATORY FAILURE CAUSED BY SARS-NCoV-2 (COVID-19)
}

\begin{abstract}
V. Skoryk, V. Korsunov
Hypoxemic respiratory failure (HRF) or acute respiratory distress syndrome is the most common and severe complication in patients with COVID-19, requiring oxygen and ventilation support. Non-invasive ventilation methods (NIV) allow to maintain adequate oxygenation in patients with HRF, but it remains unclear which NIV regimen is more effective for reducing the need for invasive ventilation and improving outcomes.

The aim. To compare the effect of different non-invasive lung ventilation strategies, namely CPAP $+P S V$ and CPAP without PSV on the results of intensive care of patients with HRF caused by SARS-nCoV-2 (COVID-19).

Materials and methods. A prospective single-center study of 59 patients with severe SARS-nCoV-2 (COVID-19) with HRF was performed. Depending on the type of NIV, patients were divided into two groups: in patients of group $1(n=46)$ respiratory support was performed in CPAP mode without PSV, in patients of group 2 ( $n=13)-$ $C P A P+P S V$. All patients underwent clinical blood tests, biochemical studies aimed at assessing the severity of COVID-19, visualization of lung tissue (chest radiography, ultrasound to determine the profile of $B$ and C), monitoring of gas exchange, echocardiography to assess the state of central hemodynamics. Statistical analysis of the results was performed using the program "Statistica 10". Estimated mean values, standard deviation. The relative risk (RR) of adverse events was assessed.
\end{abstract}

Results. The use of CPAP without PSV improves the results of intensive care of patients with severe coronavirus disease with the development of $H R F$.

Conclusions. CPAP NIV is a promising method of respiratory support in patients with moderate to severe ARDS caused by SARS-nCoV-2 virus (COVID-19), which needs further study

Keywords: SARS-nCoV-2, COVID-19, respiratory failure, respiratory distress syndrome, respiratory support, non-invasive lung ventilation

Copyright (C) 2020, V. Skoryk, V. Korsunov.

This is an open access article under the CC BY license (http://creativecommons.org/licenses/by/4.0).

\section{Introduction}

A coronavirus disease pandemic caused by a new strain of coronavirus SARS-nCoV-2 (COVID-19) is accompanied by the development of bilateral pneumonia and, in a significant proportion of patients, severe hypoxemic respiratory failure (HRF) [1]. HRF is one of the leading reasons for hospitalization of patients with coronavirus disease in intensive care units. Despite the use of modern equipment for mechanical ventilation (MV), the use of the principles of lung protective ventilation, the results of intensive therapy of respiratory failure in patients with COVID-19 remain completely unsatisfactory due to the high percentage of fatalities [2]. The current Guidelines provide guidance on several options for respiratory therapy in patients with COVID-19: low-flow oxygen therapy, high-flow nasal cannulas, non-invasive positive pressure ventilation (CPAP+PSV) and non-invasive CPAP (nCARP), invasive lung ventilation through the endotracheal tube [3].

Non-invasive ventilation methods (NIV) are a widely available tool used in severe patients and in some cases avoid tracheal intubation and the need for mechanical ventilation. It remains unclear which NIV regimen is more effective in reducing the need for invasive MV and improving outcomes [4]. However, the recommendations for the choice of NIV regimen re- main controversial, as does the assessment of its safety and impact on treatment outcomes. Among the main discussion issues, which are based on the understanding of pathophysiological processes in HRF, and have an impact on its further course, are considered some options for lung damage during respiratory therapy. These are the known phenomena VILI - ventilator induced lung injury and P-SILI - patient self-inflicted lung injury [5]. It cannot be ruled out that VILI is one of the reasons for the high rate of adverse outcomes in patients with invasive ventilation, while P-SILI - damages the lungs during both self-breathing and auxiliary ventilation with positive inspiratory pressure.

Regarding the CPAP technology, some authors note that it can both reduce the negative effects of P-SILI and reduce the need for invasive ventilation, thus preventing the development of VILI $[5,6]$. Theoretical considerations also suggest that the mechanism of P-SILI may be relevant in the conduct of NIV, which will negatively affect the course and yields of HRF in patients with COVID-19. Therefore, the assessment of the effect of two NIV regimens, namely CPAP+PSV and CPAP on the course and outputs in the treatment of HRF in patients with COVID-19 is the main goal of this study.

The aim of the research. To compare the effect of different non-invasive lung ventilation strategies, namely 
CPAP+PSV and CPAP without PSV on the results of intensive care of patients with HRF caused by SARSnCoV-2 (COVID-19).

\section{Materials and methods}

A single-center prospective cohort comparative study was conducted, which in May-August 2020 included 59 patients with severe SARS-nCoV-2 (COVID-19) with bilateral pneumonia and $\mathrm{HRF}$, which was not corrected by oxygen therapy with $\mathrm{FiO}_{2}=1.0$ and a flow of $151 / \mathrm{min}$. The study was conducted on the clinical basis of the Department of Anesthesiology, Pediatric Anesthesiology and Intensive Care of the Kharkiv Medical Academy of Postgraduate Education in the Department of Intensive Care of the municipal non-profit enterprise of the Kharkiv regional council of the regional clinical infectious hospital.

The work was carried out in accordance with the Code of Ethics of the World Medical Association (Helsinki Declaration). All patients included in the study provided written informed consent.

Depending on the NIV regimen, patients were divided into two groups. In patients of group $1(n=46)$ respiratory support was performed in CPAP mode without PSV, in patients of group $2(n=13)-C P A P+P S V$. The value of PSV was chosen according to the clinical effect and the degree of comfort of patients and averaged $4.5 \pm 1.5 \mathrm{~cm} \mathrm{H}_{2} \mathrm{O}$.

The average age of patients and anthropometric parameters in patients of both groups did not differ $(\mathrm{p}>0.05)$ (Table 1).

Table 1

Anthropometric characteristics of patients in the examined groups $(\mathrm{M} \pm \mathrm{SD})$

\begin{tabular}{|c|c|c|}
\hline Indicator & Group 1 $(\mathrm{n}=46)$ & Group 2 $(\mathrm{n}=13)$ \\
\hline Age, years & $65.2 \pm 10.3$ & $68.1 \pm 11.1$ \\
\hline Height, $\mathrm{cm}$ & $172.0 \pm 7.7$ & $170.6 \pm 7.2$ \\
\hline Weight, $\mathrm{kg}$ & $95.0 \pm 16.4$ & $91.6 \pm 15.9$ \\
\hline BMI, $\mathrm{kg} / \mathrm{m}^{2}$ & $32.2 \pm 5.7$ & $31.6 \pm 5.8$ \\
\hline BSA, $\mathrm{m}^{2}$ & $2.1 \pm 0.2$ & $2.1 \pm 0.2$ \\
\hline
\end{tabular}

The diagnosis of coronavirus disease was confirmed by the isolation of RNA SARS-nCoV-2 from nasopharyngeal lavage. Verification of pneumonia was performed by computed tomography or chest radiography. All patients underwent clinical blood tests, biochemical studies aimed at assessing the severity of COVID-19 and determining the status of vital organs and systems. formula:

Body mass index (BMI) was calculated by the

BMI=body weight $/$ height $^{2}\left(\mathrm{~kg} / \mathrm{m}^{2}\right)$.

Clinical analysis of blood was performed using an analyzer "BC - 2800 Mindray" (PRC).

Blood glucose levels were determined by glucose oxidase method, total bilirubin - using vanadic acid,
ALAT - by kinetic method (Cormay kits, Poland). Creatinine in the blood was determined by the method of Jaffa. The concentration of LDH was determined by the kinetic method, the content of total protein in the venous blood - using the biuret method, albumin - with bromochrysol green (Granum kits, Spain). The concentration of C-reactive protein was determined by turbidimetric method (Biosystems kits, Spain). All biochemical studies were performed on a biochemical analyzer "Chemray 120 Mindray" (PRC). To monitor the state of the hemostasis system, the D-dimer was determined by ELISA (Vector-Best kits, Ukraine).

Monitoring of patients included electrocardiography to determine heart rate (HR), measurement of mean arterial pressure (MAP) by oscillometric method and pulse oximetry ( $\left.\mathrm{SpO}_{2} \%\right)$ Yutas UM-300 monitors, (Ukraine), Mindray iMEC12, Biomed 800 (China).

All patients underwent daily bedside ultrasound examination of the lungs with the determination of profiles A, B, pathological B and C and echocardioscopy in M-mode using an ultrasound scanner "Ultima PA" (Ukraine). End-diastolic (EDD) and end-systolic (ESD) dimensions of the left ventricle and right ventricular EDD were measured. On the basis of the obtained data according to the formula of Teichholz L. et al., (1976) the calculation of end-systolic (ESV) and end-diastolic volumes (EDV) of the left ventricle, stroke volume (SV), ejection fraction (EF) was performed.

Cardiac output (CO) was calculated by the formula:

$$
\mathrm{CO}=\mathrm{SV} \times \mathrm{HR}
$$

Cardiac index (CI) was calculated by the formula:

\section{$\mathrm{CI}=\mathrm{CO} / \mathrm{BSA}$,}

where BSA is the body surface area according to the Mostller formula. In the presence of an ultrasound window, the mean arterial pressure in the pulmonary artery (MAP PA) was measured by Kitabatake A et al. (1983).

The calculation of oxygen delivery was performed according to the formula:

$$
\mathrm{DO}_{2}=\mathrm{CI} \times 1.39 \times \mathrm{Hb} \times \mathrm{SpO}_{2}\left(\mathrm{ml} / \mathrm{min} / \mathrm{m}^{2}\right) .
$$

Intensive care of patients was carried out according to the relevant orders of the Ministry of Health [7-11] and included the appointment of anticoagulants, corticosteroids, infusion therapy of restrictive type, antibacterial drugs as needed, use of sympathomimetics and sedatives as needed, treatment of comorbidities (coronary heart disease, diabetes, hypertension, etc.), symptomatic therapy.

All patients underwent NIV through a tight-fitting face mask with Newport E 360t, Dräger Carina, Resvent RS 300, Monnal 75t, Graph Net and Extend XT with assessment of ventilation parameters and pulmonary mechanics: Vt (ml), MV (l/min), f (for $1 \mathrm{~min})$, Pin ( $\mathrm{cm} \mathrm{H}_{2} \mathrm{O}$ ), Pmean $\left(\mathrm{cm} \mathrm{H}_{2} \mathrm{O}\right)$, PEEP $\left(\mathrm{cm} \mathrm{H}_{2} \mathrm{O}\right), \mathrm{FiO}_{2}(\%)$ using graphics monitors. The oxygen saturation index (OSI) was calculated by the formula: 


$$
\mathrm{OSI}=\left(\mathrm{FiO}_{2} \times \mathrm{Pmean} \times 100\right) / \mathrm{SpO}_{2},
$$

where $\mathrm{FiO}_{2}$ - fraction of oxygen in the gas mixture, Pmean - the average pressure in the airways.

The ROX index was determined by the formula:

$$
\mathrm{ROX}=\left(\mathrm{SpO}_{2} / \mathrm{FiO}_{2}\right) / \mathrm{RR}
$$

where RR is the frequency of respiratory rate [12].

Statistical analysis of the results was performed using the program "Statistica 10". The normality of the distribution of indicators in the samples was checked using the Kolmogorov-Smirnov test. Estimated mean values, standard deviation. Significance of differences in indicators was assessed using Student's t-test. The results were considered reliable at values of $p<0.05$. Data are presented as $\mathrm{M} \pm \mathrm{SD}$.

The relative risk (RR) of adverse events was assessed.

\section{Research results}

In the analysis of the age structure of the groups it was noted that in group 1 there were 26 patients $(56.5 \pm$ $\pm 7.3 \%)$ of the elderly and 6 patients $(13.0 \pm 5.0 \%)$ of old age, in group 2 - respectively 7 patients $(53.8 \pm 14.4 \%)$ of the elderly and $3(23.1 \pm 12.2 \%)$ of old age according to the WHO classification. Therefore, the age distribution of the examined groups of patients did not differ significantly and they were dominated by elderly patients ( $p>0.05$ ).

At the beginning of respiratory support, OSI and ROX index were determined. According to the obtained value of OSI, patients in both groups corresponded to moderate $(7.5 \leq \mathrm{OSI} \leq 12.3)$ and severe $(\mathrm{OSI} \geq 12.3)$ ARDS: in group 1 the OSI was $10.3 \pm 2.8$, and in group $2-13.6 \pm$ \pm 2.8 . However, the data obtained may not indicate a more severe course of HRF in patients of group 2, because the calculation of OSI uses Pmean, which is predicted to be higher when using PSV and, accordingly, affects the value of OSI. The ROX index in group 1 was $4.1 \pm 1.7$, and in group $2-3.6 \pm 0.8(\mathrm{p}>0.05)$.

According to chest ultrasound in patients of both groups on both sides there was a pathological profile $\mathrm{B}$ (5.0 \pm 2.0 lines) with the presence of consolidations with an area of more than $1 \mathrm{~cm}^{2}$, which corresponds to the typical ultrasound characteristics of COVID-19 pneumonia and ARDS.

Levels of total protein, bilirubin at the time of hospitalization of ICU patients corresponded to normal values and had no significant statistical differences between groups. However, patients in the examined groups showed an increase in glycemia, which indicates a violation of glucose tolerance and is considered a significant risk factor for severe coronavirus disease. The results also show that the albumin level was closer to the lower limit of normal. There was a significant increase in LDH levels, urea, creatinine and ALT levels were at the upper limit of normal. The level of C-reactive protein in group 1 was 15.5 times higher than normal, and in group 2-19 times, which indicates a significant increase without significant differences between groups ( $p>0.05)$ (Table 2).
Table 2

Comparative characteristics of biochemical data in patients of the examined groups $(\mathrm{M} \pm \mathrm{SD})$

\begin{tabular}{|c|c|c|c|}
\hline \multirow{2}{*}{ Indicator } & \multicolumn{2}{|c|}{ Groups } & \multirow{2}{*}{ Норма } \\
\cline { 2 - 3 } & $\begin{array}{c}\text { Group 1 } \\
(\mathrm{n}=46)\end{array}$ & $\begin{array}{c}\text { Group 2 } \\
(\mathrm{n}=13)\end{array}$ & \\
\hline Total protein, g/1 & $68.4 \pm 5.4$ & $65.8 \pm 3.8$ & $60-85$ \\
\hline Albumin, g/1 & $35.4 \pm 6.1$ & $35.9 \pm 2.1$ & $30-45$ \\
\hline Urea, mmol/1 & $9.5 \pm 6.4$ & $8.5 \pm 4.0$ & $2.5-8.3$ \\
\hline Creatinine, $\mu$ mol/1 & $103.6 \pm 37.6$ & $123.6 \pm 76.8$ & $44-106$ \\
\hline $\begin{array}{c}\text { Total bilirubin, } \\
\mu m o l / 1\end{array}$ & $16.1 \pm 4.3$ & $16.4 \pm 3.4$ & $3.4-20.5$ \\
\hline Glucose, mmol/1 & $9.3 \pm 4.5$ & $7.9 \pm 3.2$ & $3.3-5.5$ \\
\hline $\begin{array}{c}\text { ALT, u/1 } \\
\text { LDH, u/1 }\end{array}$ & $39.8 \pm 22.2$ & $49.8 \pm 27.8$ & $<30$ \\
\hline $\begin{array}{c}\text { C-reactive protein, } \\
\text { g/1 }\end{array}$ & $930.9 \pm 397.9$ & $848.3 \pm 142.4$ & $<195$ \\
\hline
\end{tabular}

The level of D-dimer in group 1 was $1848.3 \pm$ $\pm 2424.9 \mathrm{ng} / \mathrm{ml}$, which is significantly higher than normal ( $\mathrm{N}$ to $250 \mathrm{ng} / \mathrm{ml}$ ). The D-dimer in group 2 was $1499.3 \pm$ $\pm 1675.3 \mathrm{ng} / \mathrm{ml}$ and had no significant difference with group $1(\mathrm{p}>0.05)$. Therefore, the presence of hypercoagulable syndrome and intravascular thrombosis was noted in patients of the examined groups.

From the time of admission to the ICU, all patients began to conduct NIV. The initial level of $\mathrm{FiO}_{2}$ and PEEP in the groups did not differ. Patients of both examined groups were characterized by severe tachypnea. In group 1, the level of mean airway pressure was $11.0 \pm 2.0 \mathrm{cmH}_{2} \mathrm{O}$ and was significantly lower than in group $2-13.5 \pm 2.1 \mathrm{cmH}_{2} \mathrm{O}$ $(p=0.0003)$. Accordingly, the level of peak airway pressure was also significantly lower in group $1(\mathrm{p}=0.016)$. The results obtained may indicate that the use of PSV in NIV may increase intrathoracic pressure due to higher levels of Pmean (Table 3).

Table 3

The main indicators of respiratory mechanics and gas exchange in groups of patients at the beginning of respiratory support $(\mathrm{M} \pm \mathrm{SD})$

\begin{tabular}{|c|c|c|c|}
\hline \multirow{2}{*}{ Indicator } & \multicolumn{2}{|c|}{ Groups } & \multirow{2}{*}{$\mathrm{P}$} \\
\cline { 2 - 3 } & Group 1 (n=46) & Group 2 $(\mathrm{n}=13)$ & \\
\hline $\mathrm{RR}, \mathrm{min}^{-1}$ & $28.8 \pm 5.8$ & $28.5 \pm 3.7$ & $>0.05$ \\
\hline $\mathrm{MV}, 1 / \mathrm{min}$ & $15.3 \pm 3.6$ & $16.0 \pm 4.2$ & $>0.05$ \\
\hline $\mathrm{SpO}_{2}, \%$ & $95.4 \pm 2.1$ & $94.4 \pm 3.9$ & $>0.05$ \\
\hline $\mathrm{FiO}_{2}, \%$ & $85.6 \pm 16.1$ & $94.6 \pm 7.7$ & $>0.05$ \\
\hline $\mathrm{PEEP}_{\mathrm{cm}} \mathrm{cm} \mathrm{O}_{2}$ & $10.3 \pm 1.2$ & $10.1 \pm 1.3$ & $>0.05$ \\
\hline Pmean, $\mathrm{cm} \mathrm{H}_{2} \mathrm{O}$ & $11.0 \pm 2.0$ & $13.5 \pm 2.1$ & 0.0003 \\
\hline Ppeak, $\mathrm{cm} \mathrm{H}_{2} \mathrm{O}$ & $14.7 \pm 1.7$ & $16.5 \pm 3.3$ & 0.016 \\
\hline
\end{tabular}


On the first day of non-invasive ventilation in group 1, EDV, SV and CO corresponded to normal values [13] and were significantly higher than in group 2.

The volume of infusion therapy in the examined groups did not differ and was $1520.0 \pm 184.8 \mathrm{ml}$ in group 1 and $1531.4 \pm 211.7 \mathrm{ml}$ in group $2(\mathrm{p}>0.05)$. Only isotonic saline solutions were used for fluid therapy. Therefore, the data obtained can be regarded as a decrease in venous return, which cannot be explained by the different volume and composition of fluid therapy. Thus, venous return was significantly lower in group 2 patients than in group 1, which may be associated with significantly higher levels of Pmean, which adversely affects venous return to the left ventricle. On the second or third day from the beginning of NIV analysis of central hemodynamic parameters in patients of both groups did not reveal significant differences. ESV and SV in comparison with normal values (Table 4). However, in group 2 there was a tendency to decrease EDV,

patients died, and in group $2-12(92.3 \pm 7.7 \%)$ patients. The relative risk of death in group 1 was significantly lower than in group $2(\mathrm{RR}=0.49,95 \%$ CI $0.35-0.70$, $\mathrm{p}=0.0001)$. Therefore, the analysis of the obtained results shows that the use of CPAP without PSV improves the results of intensive care of patients with severe coronavirus disease with the development of HRF.

\section{Research results discussions}

In our study, we demonstrated the potential of NIV in severe coronavirus disease with the development of HRF.

The obtained results suggest that the patients of the examined groups had comparable HRF severity indicators, which correspond to ARDS of moderate and severe degree according to the Berlin criteria (2012).

According to anthropometric characteristics and clinical and laboratory changes, patients did not differ

The state of central hemodynamics at the stages of intensive care in groups of patients using different NIV regimens $(\mathrm{M} \pm \mathrm{SD})$

\begin{tabular}{|c|c|c|c|c|c|}
\hline \multirow{3}{*}{ Indicator } & \multicolumn{4}{|c|}{ Group } & \multirow{3}{*}{ Norm } \\
\hline & \multicolumn{2}{|c|}{ Group $1(n=46)$} & \multicolumn{2}{|c|}{ Group $2(n=13)$} & \\
\hline & 1 day & 2-3 days & 1 day & 2-3 days & \\
\hline $\begin{array}{l}\text { BPmean, } \\
\text { mm Hg }\end{array}$ & $102 \pm 14.2^{*}$ & $94.0 \pm 14.6$ & $112.8 \pm 13.5$ & $101.2 \pm 9.3$ & $70-110$ \\
\hline $\mathrm{HR}, \min$ & $91.1 \pm 20.2$ & $83.8 \pm 17.6$ & $91.6 \pm 19.1$ & $85.7 \pm 17.6$ & $60-90$ \\
\hline $\mathrm{EDD}, \mathrm{cm}$ & $5.0 \pm 0.9^{*}$ & $5.0 \pm 0.9$ & $3.8 \pm 0.6$ & $4.2 \pm 0.31$ & $3.6-5.6$ \\
\hline $\mathrm{ESD}, \mathrm{cm}$ & $3.1 \pm 0.8$ & $3.1 \pm 0.9$ & $2.6 \pm 0.5$ & $2.5 \pm 0.3$ & $2.4-5.2$ \\
\hline $\mathrm{EDV}, \mathrm{ml}$ & $122.2 \pm 55.7^{*}$ & $125.0 \pm 58.6$ & $76.3 \pm 28.0$ & $80.3 \pm 14.0$ & $80-150$ \\
\hline $\mathrm{ESV}, \mathrm{ml}$ & $42.9 \pm 29.7$ & $45.4 \pm 35.9$ & $25.2 \pm 11.1$ & $23.4 \pm 7.9$ & $30-40$ \\
\hline $\mathrm{SV}, \mathrm{ml}$ & $79.3 \pm 30.2^{*}$ & $79.6 \pm 25.2$ & $51.1 \pm 21.3$ & $56.9 \pm 9.4$ & $70-100$ \\
\hline $\mathrm{EF}, \%$ & $66.6 \pm 10.5$ & $64.4 \pm 14.6$ & $66.3 \pm 10.2$ & $71.1 \pm 6.8$ & $55-75$ \\
\hline $\mathrm{CI}, 1 / \mathrm{min} / \mathrm{m}^{2}$ & $3.5 \pm 1.5$ & $2.9 \pm 0.9$ & $2.3 \pm 1.3$ & $2.7 \pm 0.3$ & $3-4$ \\
\hline $\mathrm{CO}, 1 / \mathrm{min}$ & $7.3 \pm 3.2^{*}$ & $6.0 \pm 1.6$ & $4.8 \pm 2.4$ & $5.6 \pm 0.7$ & $3.5-5.5$ \\
\hline $\begin{array}{c}\mathrm{DO}_{2} \\
\mathrm{ml} / \mathrm{min}^{2} \mathrm{~m}^{2}\end{array}$ & $521.7 \pm 231.6$ & $616.9 \pm 118.6$ & $445.8 \pm 209.9$ & $554.0 \pm 121.5$ & $500-600$ \\
\hline
\end{tabular}

Note: ${ }^{*}-(p<0.05)$ - the significance of the differences between groups 1 and 2 on the first day

The average duration of respiratory support in group 1 was $6.21 \pm 5.2$ days, and in group $2-4.13 \pm 2.3$ days with a minimum value of 1 day in both groups and a maximum of 29 days in group 1, and 8 days - in group 2, but had no significant differences between groups ( $p>0.05$ ).

In case of inefficiency of NIV, patients of the examined groups were transferred to invasive ventilation. In group 1 there were 16 patients $(34.78 \pm 7 \%$ ), and in group $2-4(30.8 \pm 13.3 \%)$. According to this indicator, the groups did not differ significantly $(\mathrm{p}>0.05)$.

In the analysis of mortality in the groups, the aver-

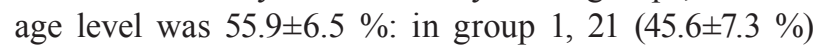

Table 4

from the data presented in other modern publications. The vast majority of patients were over 60 years of age and were overweight. The obtained data support the fact that old age and overweight are risk factors for severe COVID-19 [14, 15].

Laboratory examination revealed high levels of ALT, LDH, C-reactive protein and D-dimer, which is also consistent with the work of foreign authors $[1,14,15]$. Based on current literature on the issue of coronavirus disease, a significant increase in C-reactive protein is one of the indicators of the development of cytokine storm and adverse course of the disease $[16,17]$.

The use of NIV in SARS-nCoV-2 since the beginning of the pandemic has caused controversy, as it was believed that its use increases aerosolization in intensive care units [3]. But later it was shown that there is no convincing data that would confirm the increase of aerosolization when using non-invasive techniques [18-20].

In addition, studies have shown an increase in mortality with NIV due to delayed tracheal intubation, but did not specify which respiratory support regimen was used. However, invasive ventilation in patients with SARS-nCoV-2 worldwide has a high mortality rate (up to $92 \%$ ), so the question of the possibility of NIV in patients with HRF caused by coronavirus disease remains controversial [21].

One Chinese study compared the effects on invasive and non-invasive lung outcomes and obtained convincing results in favour of NIV: mortality in the invasive ventilation group was $92 \%(n=104)$ and in the NIV group was $40.8 \%(\mathrm{n}=62),(\mathrm{p}<0.001)$. Unfortunately, the authors do not specify which mode of ventilation was used. However, the results are comparable with the results of our study in group 1, where mortality was $45.6 \%(n=21)[18]$. 
In modern publications, we have not found a comparison of the use of different NIV modes in COVID-19. In our study, we demonstrated the effect of different NIV regimens on hemodynamics. Due to the increase in intrathoracic pressure when using CPAP+PSV, the preload of the left ventricle is reduced. Therefore, it can be assumed that the use of CPAP+PSV has a negative effect on hemodynamics and long-term consequences in patients with severe coronavirus disease [22].

Therefore, given the previous results of intensive care in a small sample of patients, we consider the use of NIV in CPAP mode without PSV as a tool to improve oxygenation and results in patients with COVID-19.

Study limitations. The limitations of the study are related to a small sample of patients.

Prospects for further research. The study of the effect of non-invasive ventilation regimens in patients with moderate and severe ARDS caused by SARSnCoV-2 virus (COVID-19) will be further developed.

\section{Conclusions}

1. The use of non-invasive ventilation in CPAP mode in patients with severe SARS-nCoV-2 (COVID-19), accompanied by the development of moderate and severe ARDS, allows to maintain adequate oxygenation
$\left(\mathrm{SpO}_{2}>94 \%, \mathrm{RR}<32 \mathrm{~min}^{-1}\right)$ and does not worsen the indicators of central hemodynamics (CI $3.5 \pm 1.5 \mathrm{l} / \mathrm{min} / \mathrm{m}^{2}$, SV $79.3 \pm 30.2 \mathrm{ml})$.

2. The use of NIV in the mode of CPAP+PSV also allows to maintain an adequate level of oxygenation $\left(\mathrm{SpO}_{2}>94 \%, \mathrm{RR}<32 \mathrm{~min}^{-1}\right)$ in patients with severe ARDS, but has a negative effect on central hemodynamics (CI $2.3 \pm 1.3 \mathrm{l} / \mathrm{min} / \mathrm{m}^{2}$, SV $51.1 \pm 21.3 \mathrm{ml}$ ).

3. The mortality rate with the use of NIV in the CPAP regimen in patients with ARDS caused by SARSnCoV-2 in our study was $45.6 \%$, and with CPAP+PSV this figure was $92.3 \%$, which is comparable to current publications.

4. The relative risk of adverse outcome in patients with HRF caused by SARS-nCoV-2 virus (COVID-19) when using NIV in CPAP mode is significantly lower than in the group using CPAP+PSV ( $\mathrm{RR}=0.49,95 \% \mathrm{CI} 0.35$ $0.70, \mathrm{p}=0.0001$ ), which allows us to consider NIV in the CPAP mode a promising method of respiratory support in patients with moderate and severe ARDS caused by SARSnCoV-2 virus (COVID-19), which requires further study.

\section{Conflict of interest}

The authors declare that they have no conflicts of interest.

\section{References}

1. Alhazzani, W., Møller, M. H., Arabi, Y. M., Loeb, M., Ng Gong, M., Fan, E., Oczkowski, S. (2020). Surviving Sepsis Campaign: guidelines on the management of critically ill adults with Coronavirus Disease 2019 (COVID-19). Intensive Care Med, 46 (5), 854-887. doi: http://doi.org/10.1007/s00134-020-06022-5

2. Weiss, P., Murdoch, D. R. (2020). Clinical course and mortality risk of severe COVID-19. The Lancet, 395 (10229), 10141015. doi: http://doi.org/10.1016/s0140-6736(20)30633-4

3. Díaz Lobato, S., Carratalá Perales, J. M., Alonso Íñigo, J. M. (2020). Can we use noninvasive respiratory therapies in COVID-19 pandemic? Medicina Clínica, 155 (4), 183. doi: http://doi.org/10.1016/j.medcle.2020.05.005

4. Winck, J. C., Ambrosino, N. (2020). COVID-19 pandemic and non invasive respiratory management: Every Goliath needs a David. An evidence based evaluation of problems. Pulmonology, 26 (4), 213-220. doi: http://doi.org/10.1016/j.pulmoe.2020.04.013

5. Yoshida, T., Amato, M. B. P., Kavanagh, B. P., Fujino, Y. (2019). Impact of spontaneous breathing during mechanical ventilation in acute respiratory distress syndrome. Current Opinion in Critical Care, 25 (2), 192-198. doi: http://doi.org/10.1097/ mcc.0000000000000597

6. Kofod, L. M., Jeschke, K. N., Krogh-Madsen, R. (2020). CPAP for patients with COVID-19. Ugeskr Laeger, 182 (33), V05200358.

7. Orhanizatsiia nadannia medychnoi dopomohy khvorym na koronavirusnu khvorobu (COVID-19) (2020). Nakaz MOZ Ukrainy No. 722. 28.03.2020. Available at: https://moz.gov.ua/article/ministry-mandates/nakaz-moz-ukraini-vid-28032020--722-organizacija-nadannja-medichnoi-dopomogi-hvorim-na-koronavirusnu-hvorobu-covid-19

8. Pro zatverdzhennia protokolu «Nadannia medychnoi dopomohy dlia likuvannia koronavirusnoi khvoroby (COVID-19) (2020). Nakaz MOZ Ukrainy No. 762. 02.04.2020. Available at: https://zakon.rada.gov.ua/rada/show/v0762282-20\#Text

9. Pro vnesennia zmin do protokolu «Nadannia medychnoi dopomohy dlia likuvannia koronavirusnoi khvoroby (COVID-19) (2020). Nakaz MOZ Ukrainy No. 852. 10.04.2020. Available at: https://moz.gov.ua/article/ministry-mandates/nakaz-moz-ukrainivid-10042020--852-pro-vnesennja-zmin-do-protokolu-nadannja-medichnoi-dopomogi-dlja-likuvannja-koronavirusnoi-hvorobi-covid-19

10. Pro vnesennia zmin do dodatku 6 Standartiv medychnoi dopomohy Koronavirusna khvoroba (COVID-19) (2020). Nakaz MOZ Ukrainy No. 994. 30.04.2020. Available at: https://moz.gov.ua/article/ministry-mandates/nakaz-moz-ukraini-vid-30042020--9 94-pro-vnesennja-zmin-do-dodatku-6-do-standartiv-medichnoi-dopomogi-koronavirusna-hvoroba-covid-19?fbclid=IwAR33mic2ujI-Oo2jgmL3P3gHAhnY6Ext2NedcVyjNfbqLt164Vm0aaNrps4

11. Pro vnesennia zmin do Standartiv medychnoi dopomohy Koronavirusna khvoroba (COVID-19) (2020). Nakaz MOZ Ukrainy No. 1411. 16.06.2020. Available at: https://moz.gov.ua/article/ministry-mandates/nakaz-moz-ukraini-vid-16062020--1411-p ro-vnesennja-zmin-do-standartiv-medichnoi-dopomogi-koronavirusna-hvoroba-covid-19?fbclid=IwAR3BPUvjcszRmBeEYnP86ahLUqaVNx_dgeGpPm021F8tM5yybsk5wE3GFN0

12. Mauri, T., Carlesso, E., Spinelli, E., Turrini, C., Corte, F. D., Russo, R. et. al. (2019). Increasing support by nasal high flow acutely modifies the ROX index in hypoxemic patients: A physiologic study. Journal of Critical Care, 53, 183-185. doi: http:// doi.org/10.1016/j.jcrc.2019.06.020 
13. Otto, C. M., Pearlman, A. S. (Eds.) (1995). Textbook of Clinical Echocardiography. Philadelphia: WB Saunders Co, $243-278$.

14. Yang, J., Zheng, Y., Gou, X., Pu, K., Chen, Z., Guo, Q. et. al. (2020). Prevalence of comorbidities and its effects in patients infected with SARS-CoV-2: a systematic review and meta-analysis. International Journal of Infectious Diseases, 94, 91-95. doi: http:// doi.org/10.1016/j.ijid.2020.03.017

15. Rodriguez-Morales, A. J., Cardona-Ospina, J. A., Gutiérrez-Ocampo, E., Villamizar-Peña, R., Holguin-Rivera, Y., Escalera-Antezana, J. P. et. al. (2020). Clinical, laboratory and imaging features of COVID-19: A systematic review and meta-analysis. Travel Medicine and Infectious Disease, 34, 101623. doi: http://doi.org/10.1016/j.tmaid.2020.101623

16. Wu, Z., McGoogan, J. M. (2020). Characteristics of and Important Lessons From the Coronavirus Disease 2019 (COVID-19) Outbreak in China. JAMA, 323 (13), 1239. doi: http://doi.org/10.1001/jama.2020.2648

17. Wang, L. (2020). C-reactive protein levels in the early stage of COVID-19. Médecine et Maladies Infectieuses, 50 (4), 332-334. doi: http://doi.org/10.1016/j.medmal.2020.03.007

18. Moret Iurilli, C., Brunetti, N. D., Di Corato, P. R., Salvemini, G., Di Biase, M., Ciccone, M. M., Procacci, V. (2018). Hyperacute Hemodynamic Effects of BiPAP Noninvasive Ventilation: To(o) Di(uretics) or Not To(o) Di(uretics)? Journal of Intensive Care Medicine, 33 (12), 697. doi: http://doi.org/10.1177/0885066618758617

19. Wang, D., Yin, Y., Hu, C., Liu, X., Zhang, X., Zhou, S. et. al. (2020). Clinical course and outcome of 107 patients infected with the novel coronavirus, SARS-CoV-2, discharged from two hospitals in Wuhan, China. Critical Care, 24 (1). doi: http:// doi.org/10.1186/s13054-020-02895-6

20. Hua, J., Qian, C., Luo, Z., Li, Q., Wang, F. (2020). Invasive mechanical ventilation in COVID-19 patient management: the experience with 469 patients in Wuhan. Critical Care, 24 (1). doi: http://doi.org/10.1186/s13054-020-03044-9

21. Rochwerg, B., Brochard, L., Elliott, M. W., Hess, D., Hill, N. S., Nava, S. et. al. (2017). Official ERS/ATS clinical practice guidelines: noninvasive ventilation for acute respiratory failure. European Respiratory Journal, 50 (2), 1602426. doi: http:// doi.org/10.1183/13993003.02426-2016

22. Oranger, M., Gonzalez-Bermejo, J., Dacosta-Noble, P., Llontop, C., Guerder, A., Trosini-Desert, V. et. al. (2020). Continuous positive airway pressure to avoid intubation in SARS-CoV-2 pneumonia: a two-period retrospective case-control study. European Respiratory Journal, 56 (2), 2001692. doi: http://doi.org/10.1183/13993003.01692-2020

Received date 05.08.2020

Accepted date 11.09.2020

Published date 30.09.2020

Vita Skoryk, Postgraduate Student, Department of Anesthesiology, Pediatric Anesthesiology and Intensive Care, Kharkiv Medical Academy of Postgraduate Education, Amosova str., 58, Kharkiv, Ukraine, 61176

E-mail: vitaskoryk@gmail.com

Volodymyr Korsunov, MD, Professor, Department of Anesthesiology, Pediatric Anesthesiology and Intensive Care, Kharkiv Medical Academy of Postgraduate Education, Amosova str., 58, Kharkiv, Ukraine, 61176

E-mail: korsunoff@ukr.net 